(RESEARCH ARTICLE)

\title{
Germination response of velvet tamarind (Dialium guineense Willd.) seeds treated with pre-sowing soaking in water at varying temperatures and durations
}

\author{
Ogbu Justin U. ${ }^{{ }^{*}}$ and Otah Okocha I. ${ }^{2}$ \\ ${ }^{1}$ Department of Horticulture and Landscape Technology, Federal College of Agriculture (FCA), Ishiagu 491105 Ebonyi \\ State Nigeria \\ ${ }^{2}$ Department of Horticulture technology, AkanuIbiam Federal Polytechnic, Unwana Afikpo Ebonyi State Nigeria
}

Publication history: Received on 07 September 2017; revised on 06 October 2017; accepted on 07 November 2017

https://doi.org/10.30574/gscbps.2017.1.2.0014

\begin{abstract}
The study evaluated Dialium guineense Willd. seeds response to pre-soaking in water for varying durations and temperature regimes, as a way of addressing the species seed dormancy challenge. Experimental laid out used was $2 \mathrm{x}$ 4 factorial experiment in completely randomized design $(\mathrm{r}=4)$. Daily germination counts were taken for ten weeks after sowing. Data were analyzed by use of descriptive statistics and ANOVA at $p<0.05$. Results showed that germination started within the first seven days after sowing (DAS) for most of the treatments, but was erratic and neither uniform nor massive without effective pre-sowing treatment practice. Only seeds soaked in $75{ }^{\circ} \mathrm{C}$ water for 6 hours reached highest $52.5 \%$ cumulative germination at 70 DAS, which was followed by seeds soaked in warm water at $45{ }^{\circ} \mathrm{C}$ for 6 hours that had $40 \%$ cumulative germination. Pre-soaking in water at $30{ }^{\circ} \mathrm{C}$ had the least germination performance among the treatments evaluated. Comparison of the two treatment factors (soaking duration and temperature) showed that water at higher temperature regime of $75{ }^{\circ} \mathrm{C}$ was most impactful in eliciting improvement in total germination of $D$. guineense up to $52.5 \%$ than soaking duration alone. Six hour soaking gave higher mean total germination $(31.4 \pm 2.19 \%)$ than 12 hour pre-soaking $(29.7 \pm 4.06 \%)$, irrespective of the water temperature. The study has open up opportunity to explore further the optimum higher temperature regimes for pre-soaking in water that will boost massive uniform germination at the earliest possible time; since pre-soaking treatment in water remains safest for both the grower and seed itself among other dormancy breaking methods.
\end{abstract}

Keywords: Dialium guineense; Dormancy; Germination; Fruit tree; Pre-sowing treatments.

\section{Introduction}

Velvet tamarind (Dialium guineese Willd.) is a woody plant which occurs in the rain forest region of West Africa. It belongs to the family Fabaceae. It grows up to $15 \mathrm{~m}$ high with dark green leaves of $6-8 \mathrm{~cm}$ length and $2.5 \mathrm{~cm}$ wide at the broadest portion of the leaf [1-2]. The fresh leaves are occasionally chewed for its tangy taste. The fruits are available from January to May but the peak time frame for gather is amongst March and April [3]. Because of its refreshing properties and pleasant taste, the velvet tamarind pulp is consumed in southeastern Nigeria where it is known as: "Akin", "Icheku", "Nchichi", "Nkwa", "Ukuk" [1, 4-5]. Every fruit contains only one firm seed which is flat, circular, brown and white, a width of 7-8 mm, and a thickness of $3 \mathrm{~mm}$ (Figure 1).

\footnotetext{
${ }^{*}$ Corresponding author

E-mail address: ogbujugo@ gmail.com
}

Copyright (C) 2017 Author(s) retain the copyright of this article. This article is published under the terms of the Creative Commons Attribution Liscense 4.0. 


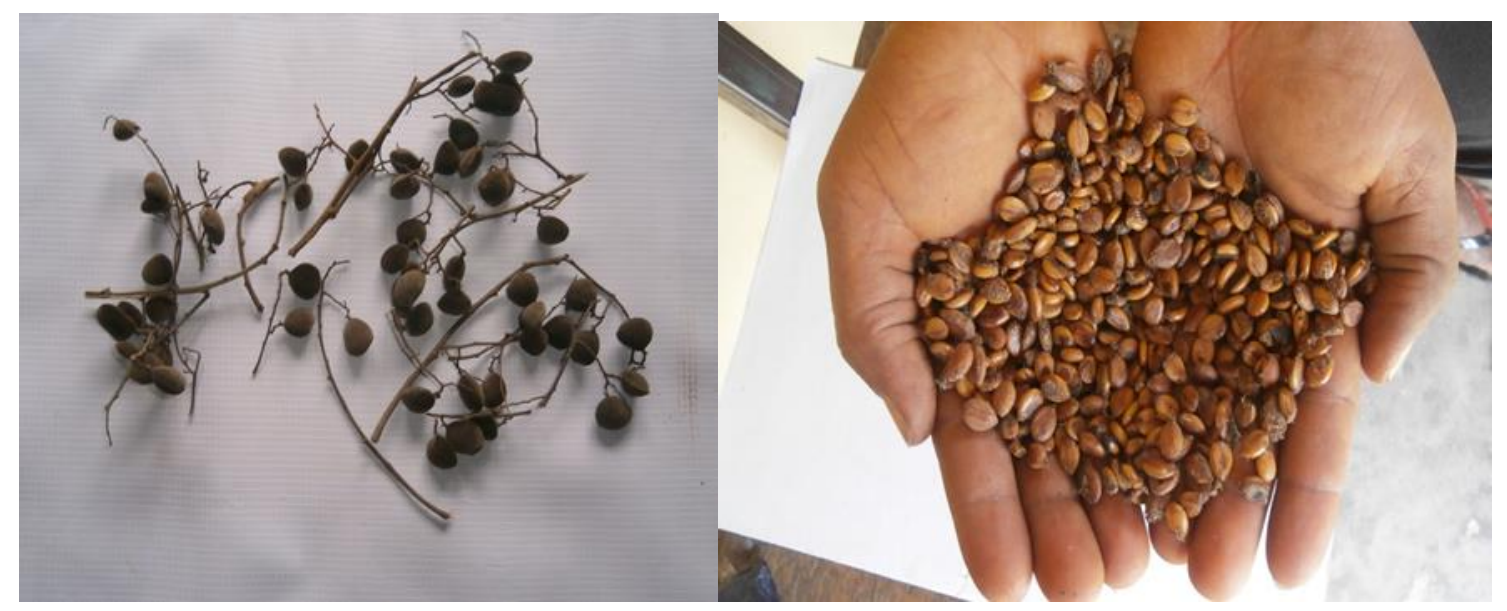

Figure 1 Fruits (left) and seeds (right) of velvet tamarind (Dialium guineense)

The fruits contain fibre, sugars (namely, fructose, glucose, sucrose and maltose, acids, polysaccharides, small amount of protein and lipid [6]. The fruit is mostly valued for its high ascorbic acid content, minerals and sugar. Velvet tamarind has a lot of ethnomedical values. The leaf decoction is used to solve problems of tooth ache. Also the bark lowers the inflammation from the bronchial tubes solving bronchitis; the leaves decoction is also used in the treatment of jaundice, regulates the blood sugar levels and intensifies the insulin sensitivity, thus curing diabetes. The excellent and gastric property of the fruit in nullifying the menstrual pain has also been reported. Velvet tamarind is very important in preventing diarrhea. The pre-mature leaves of the velvet tamarind wound healing activity [2].

The plant had never been cultivated, so the process of propagation is not clearly known, but is estimated of growing from the seeds in the forests. Considering its seed dormancy challenge and the implication in this species multiplication, it becomes necessary to determine the germination response of its seeds when treated with presowing soaking in water. Therefore, this research will be of help to the local farmers who may have interest in raising velvet tamarind seedlings. This research aimed at the study of velvet tamarind germination behavior in relation to pre-germination treatments. Specific objective of the study included: to assay germination behavior of velvet tamarind seeds; to determine effect of pre-sowing soaking duration in water and temperature of water on germination of velvet tamarind seeds; and to determine combined effect of soaking duration and temperature on breaking dormancy challenge of velvet tamarind seeds using water.

\section{Material and methods}

\subsection{Location of the study}

This research work was carried out at greenhouse of the Department of Horticulture and Landscape technology, Federal College of Agriculture Ishiagu Ebonyi State southeast Nigeria. Ishiaguis located at latitude of $05^{\circ} 56^{\prime}$ North, longitude of $007^{\circ} 32^{\prime}$ East and elevation of $59 \mathrm{~m}$ above sea level. The location mean annual rainfall and temperature records are $1655 \mathrm{~mm}$ and $29.4^{\circ} \mathrm{C}$, respectively. Its relative humidity is about $69 \%$ during dry season [7].

\subsection{Seed collection and preparation}

Matured ripened fruits of D. guineense were bought from Eke market in Ishiagu, Ebonyi State South East Nigeria. The fruit were de-pulped and their seeds extracted manually before shade drying for two days. Mixture of river sand and saw dust were used as the growth media. They were mixed at ratio of $1: 1(\mathrm{v} / \mathrm{v})$ before bagging them in polythene bags of $42 \times 50 \mathrm{~cm}$ dimension when laid flat.

\subsection{Experimental design and planting operation}

The experimental design was factorial experiment in completely randomized design. There were eight treatments combinations composed of two soaking durations ( 6 and 12 hours) and four water temperature regimes of 30, 45, 60 and $75^{\circ} \mathrm{C}$. The treatments were replicated four times. The seeds were sown in polyethylene bagged growth media and laid under nursery shade. Standard nursery practices were observed; while daily germination counts were taken for ten weeks after sowing. 


\subsection{Data collection}

Cumulative germination frequencies, day to first germination and total germination percent were calculated for each treatment. Explanations of the measurements taken are hereby stated:

- Germination counts at 7, 14, 21, 28, 35, 42, 49, 56, 63 and 70 days after sowing (DAS) per treatment was computed from daily germination counts. This was used to compute cumulative germination percentage over the period of 10 weeks [8-9].

- $\quad$ Days to first germination (i.e. number of day(s) from sowing day that the first germination was recorded [DAS]) per treatment. The emergence of hypocotyl at the growth medium surface was used as evidence of seed germination throughout the experiments as in Awodoyin et al. [8] and Rao et al. [10].

- $\quad$ Total germination percentage at $70 \mathrm{DAS}=$ the number of germinated seeds from a seed lot /total number of seeds sown, expressed as a percentage [9].

\subsection{Data analysis}

Germination data were analyzed using descriptive statistics and analysis of variance (ANOVA), while treatment mean separation was done using least significant difference (LSD) at $\mathrm{p}<0.05$.

\section{Results and discussion}

Germination started within the first seven days after sowing (7 DAS) for most of the treatments (Table 1). From the cumulative germination percent, it is obvious the dormancy challenge of Dialium guineense seeds, as at 35 DAS none of the treatments had reached $50 \%$ germination. Treatments one and two which were seeds soaked in $30{ }^{\circ} \mathrm{C}$ (near room temperature) for varying durations had the least impressive germination of not more than $22.5 \%$ by 70 DAS. Only seeds soaked in $75{ }^{\circ} \mathrm{C}$ hot water for 6 hours could reach highest $52.5 \%$ cumulative germination at 70 DAS in one of the trials, which was followed by seeds soaked in $45{ }^{\circ} \mathrm{C}$ warm water for 6 hours that had $40 \%$ cumulative germination percent. Therefore, it can be deduced from the cumulative germination that seed germination in $D$. guineense may start from the first week after sowing, but erratic and neither uniform nor massive without effective pre-sowing treatment practice.

Table 1 Cumulative germination percent of Dialium guineense across ten weeks after sowing (for first and second trials)

\begin{tabular}{|c|c|c|c|c|c|c|c|c|c|c|c|c|c|c|c|c|}
\hline \multirow[t]{2}{*}{ Days } & \multicolumn{2}{|c|}{ T 1} & \multicolumn{2}{|c|}{ T 2} & \multicolumn{2}{|c|}{ T 3} & \multicolumn{2}{|c|}{ T 4} & \multicolumn{2}{|c|}{ T 5} & \multicolumn{2}{|c|}{ T 6} & \multicolumn{2}{|c|}{ T 7} & \multicolumn{2}{|c|}{ T 8} \\
\hline & $1^{\text {st }}$ & $2^{\text {nd }}$ & $1^{\text {st }}$ & $2^{\text {nd }}$ & $1^{\text {st }}$ & $2^{\text {nd }}$ & $1^{\text {st }}$ & $2^{\text {nd }}$ & $1^{\text {st }}$ & $2^{\text {nd }}$ & $1^{\text {st }}$ & $2^{\text {nd }}$ & $1^{\text {st }}$ & $2^{\text {nd }}$ & $1^{\text {st }}$ & $2^{\text {nd }}$ \\
\hline $0-7$ & 2.5 & 0 & 7.5 & 0 & 5 & 5 & 0 & 7.5 & 7.5 & 12.5 & 7.5 & 7.5 & 7.5 & 10 & 25 & 2.5 \\
\hline $8-14$ & 12.5 & 2.5 & 7.5 & 0 & 15 & 15 & 5 & 12.5 & 17.5 & 15 & 25 & 10 & 10 & 22.5 & 10 & 15 \\
\hline $15-21$ & 15 & 5 & 10 & 0 & 15 & 17.5 & 5 & 15 & 22.5 & 17.5 & 25 & 12.5 & 10 & 27.5 & 12.5 & 17.5 \\
\hline $22-28$ & 15 & 7.5 & 10 & 2.5 & 15 & 17.5 & 10 & 15 & 22.5 & 17.5 & 25 & 12.5 & 15 & 32.5 & 20 & 17.5 \\
\hline 29-35 & 15 & 12.5 & 12.5 & 10 & 15 & 20 & 12.5 & 15 & 22.5 & 17.5 & 25 & 20 & 20 & 35 & 20 & 22.5 \\
\hline $36-42$ & 15 & 15 & 15 & 15 & 15 & 20 & 22.5 & 17.5 & 22.5 & 20 & 25 & 20 & 20 & 37.5 & 22.5 & 25 \\
\hline $43-49$ & 15 & 15 & 15 & 17.5 & 17.5 & 32.5 & 30 & 20 & 25 & 22.5 & 27.5 & 22.5 & 20 & 42 & 30 & 32.5 \\
\hline 50-56 & 20 & 20 & 20 & 17.5 & 22.5 & 35 & 32.5 & 22.5 & 30 & 27.5 & 30 & 25 & 31.5 & 50 & 35 & 32.5 \\
\hline $57-63$ & 20 & 20 & 20 & 20 & 22.5 & 35 & 32.5 & 22.5 & 30 & 27.5 & 30 & 25 & 42.5 & 50 & 35 & 32.5 \\
\hline 64-70 & 22.5 & 20 & 22.5 & 22.5 & 22.5 & 35 & 40 & 22.5 & 30 & 27.5 & 37.5 & 25 & 32.5 & 52.5 & 35 & 32.5 \\
\hline
\end{tabular}

Soaking in cold water at $30^{\circ} \mathrm{C}$ for $6 \mathrm{hrs}$ (TI) and for $12 \mathrm{hrs} \mathrm{(T2);} \mathrm{soaking} \mathrm{in} \mathrm{a} \mathrm{warm} \mathrm{water} \mathrm{at} 45^{\circ} \mathrm{C}$ for $6 \mathrm{hrs}$ (T3) and for $12 \mathrm{hrs}$ (T4); Soaking in a warm water at $60^{\circ} \mathrm{C}$ for $6 \mathrm{hrs}$ (T5) and for $12 \mathrm{hrs}$ (T6); Soaking in a hot water at $75^{\circ} \mathrm{C}$ for $6 \mathrm{hrs}$ (T7) and for 12 hrs (T8). 
Day to first germination was earliest (6.8 DAS \pm 1.48 ) in seeds that received 6 hours soaking in hot water at $60{ }^{\circ} \mathrm{C}$, which was not significantly different from the second earliest (9.9 DAS \pm 2.13 ) that also received 6 hour soaking in 75 ${ }^{\circ} \mathrm{C}$ water (Table 2).

Table 2 Day to first germination and total germination of Dialium guineense at 10 weeks after germination

\begin{tabular}{lll}
\hline Treatments & Day to first germination & Total germination (\%) \\
\hline 6 hour at $30^{\circ} \mathrm{C}$ water & $18.8 \pm 11.12$ & $21.3 \pm 1.25$ \\
12 hour at $30^{\circ} \mathrm{C}$ water & $30.8 \pm 11.00$ & $22.5 \pm 0.0$ \\
6 hour at $45^{\circ} \mathrm{C}$ water & $17.3 \pm 5.25$ & $32.5 \pm 2.50$ \\
12 hour at $45^{\circ} \mathrm{C}$ water & $18.6 \pm 2.95$ & $31.3 \pm 8.75$ \\
6 hour at $60^{\circ} \mathrm{C}$ water & $6.8 \pm 1.48$ & $30.0 \pm 2.50$ \\
12 hour at $60^{\circ} \mathrm{C}$ water & $34.9 \pm 25.13$ & $31.3 \pm 6.25$ \\
6 hour at $75^{\circ} \mathrm{C}$ water & $9.8 \pm 2.13$ & $42.5 \pm 10.00$ \\
12 hour at $75^{\circ} \mathrm{C}$ water & $15.6 \pm 0.88$ & $33.8 \pm 1.25$ \\
LSD $(0.05)$ & 4.00 & 8.14 \\
Soaking duration & & \\
6 hour & $11.7 \pm 2.6$ & $31.7 \pm 2.19$ \\
12 hour & $18.2 \pm 3.75$ & $29.7 \pm 4.06$ \\
Temperature regime & & \\
$30{ }^{\circ} \mathrm{C}$ & $22.9 \pm 9.19$ & $21.9 \pm 0.63$ \\
$45^{\circ} \mathrm{C}$ & $17.9 \pm 4.38$ & $31.9 \pm 3.13$ \\
$60{ }^{\circ} \mathrm{C}$ & $7.0 \pm 0.13$ & $30.6 \pm 4.38$ \\
$75{ }^{\circ} \mathrm{C}$ & $11.9 \pm 0.63$ & $38.1 \pm 4.4$ \\
Interaction & $* *$ & $*$ \\
LSD $(0.05)$ & 2.83 & 6.18 \\
\hline & Values are mean $\pm \mathrm{SD} ; \mathrm{n}=40 ; * *=$ significant at $\mathrm{p}<0.01 ; * \mathrm{p}<0.05$. \\
\hline
\end{tabular}

Main effect of the factors on day to first germination showed that 6 hour pre-soaking duration in water prompted earlier germination (11.7 DAS \pm 2.60 ) of $D$. guineense seeds than 12 hour soaking treatment (18.1 DAS \pm 3.75 ). Similarly, soaking in $60{ }^{\circ} \mathrm{C}$ hot water gave earliest germination (7.0 DAS \pm 0.14 ) that was remarkably better than the other temperature regimes. The mean total germination for the two trials was highest $(42.5 \% \pm 10.00)$ in seeds that were pre-soaked for 6 hours in hot water at $75^{\circ} \mathrm{C}$, while the least was recorded among the seeds given 6 hour pre-soaking in warm water at $30{ }^{\circ} \mathrm{C}$. Moreover similar trend of marginal increase in percent total germination were observed among seeds soaked for 6 hours $(31.6 \% \pm 2.19)$ than 12 hour pre-soaking treatments irrespective of the temperature regimes. In addition hot water at $75{ }^{\circ} \mathrm{C}$ temperature regime had greatest boost $(38.1 \% \pm 4.4)$ on total germination of $D$. guineense seeds, though marginal but was significantly higher than the second highest mean total germination $(31.9 \% \pm 3.13)$.

Seed germination had been explained as resumption of growth of quiescent embryo and emergence of radicle from its covering structures. During the process which may last from few days to several weeks/months, seed imbibes water, seed coat is ruptured and there are occurrence of cell division and elongation. The appearance of radicle marks the end of germination and the beginning of seedling development, a period that ends when the seedling has exhausted the food reserves in the seed [10]. The factors like water, oxygen, light and suitable temperature are very essential for seed germination. Seeds of different species have different requirements/duration, and no general set of conditions can be relied upon to germinate seeds of all species. However, difficulty in germination as a result of dormancy is often observed with seeds of Fabaceae (the legume groups including Dialium guineense), although this is not peculiar to them [11-13]. 
Seeds of D. guineense, being typically characterized by thin impervious seed coat (physical dormancy), consequently, need pretreatment practices like pre-sowing soaking in water to accelerate germination since it facilitates the infiltration of oxygen and water in the kernel that triggers the germination process [14-15]. The duration of presoaking treatment in water apart from temperature of water seemed to play pivotal role in affecting rate of germination as longer immersion could be adverse and suffocating to the seeds to proceed with normal respiration, photosynthesis and other growth processes, unlike shorter duration. This might explain the reason behind relatively poor germination percent and rate recorded among D. guineense seeds soaked for 12 hours than those of 6 hours soaking. Similar observations have been reported with other plant species, including Maesobotrya barteri (family Euphorbiaceae) and Pentaclethra macrophylla (family Fabaceae) [16-17]. With reference to temperature of water for pre-soaking, reports [15, 18-19] have shown temperature treatment as another way to pretreat seeds in order to boost germination rate. With higher temperatures, germination rate was very high (about 90-100\%) in P. macrophylla seeds [15].

In comparison of the two treatment factors, this factorial experiment had shown that water at higher temperature regime of $75{ }^{\circ} \mathrm{C}$ could be more impactful in eliciting improvement in total germination of D. guineense up to $52.5 \%$ than soaking duration alone. However, interaction effect of the two factors was also positively impressive and significant $(\mathrm{p}<0.05)$ throughout the trials in all the parameters measured. Both water and temperature are critical factors in germination and subsequent seedling growth [7, 13], as water provides solvent for dissolution of stored biochemical solutes as well as medium for their mobilization to destinations where they are needed. While temperature is known to affect the rate of biochemical processes, affecting state of solutes, solvents, and the enthalpy of the biological system. This fact may explain the reason behind some positive impacts of raised temperature regimes and soaking in water on germination of D. guineense [18-19].

\section{Conclusion}

The experiment is not yet conclusive as the germination results obtained from the treatments combination was not high enough $(\geq 80 \%)$ for recommendation. Despite the general unimpressive total germination of $D$. guineense seeds due to persisting inherent dormancy challenge, the study has open up opportunity to explore further the optimum higher temperature regimes for pre-sowing soaking in water that will boost massive uniform germination at the earliest possible time without endangering the seed and developing seedling vigour. Besides, the use of pre-soaking treatment in water remains safest for both the grower and seed itself as dormancy breaking method among other chemical methods like use of concentrated acids.

\section{Compliance with ethical standards}

\section{Acknowledgments}

The permission of Department of Horticulture and Landscape technology Federal College of Agriculture (FCA), Ishiagu Ebonyi State to use some of her facilities for this research is hereby acknowledged.

\section{Disclosure of conflict of interest}

There is no conflict of interest among the authors.

\section{References}

[1] Keay RWJ. (1989). Trees of Nigeria. Oxford University Press, New York, 216.

[2] Okegbile EO and Taiwo EA. (1990). Nutritional potentials of Velvet tamarind (Dialium guineense Willd) Niger. Food Journal, 8, 115-121.

[3] Okigbo BN. (1980). Plants and food in Igbo culture. Ahiajioku lecture series. Government Press, Owerri, Nigeria, 14-21, 37-41.

[4] Etukudo I. (2000). Forest: our dive treasure. Durand Publishers, Uyo Nigeria, 156.

[5] Onwuka GI. (2005). Food Analysis and Instrumentation (theory and practice), Naphthali Print, Lagos Nigeria.

[6] Okeke EC, Ene-obong HN, Uzuegbunam AO, Ozioko A, Umeh SI and Chukwuone N. (2009). The Igbo traditional food system documented in four states in southern Nigeria. In Indigenous people food systems. FAO and Centre for Indigenous People's Nutrition and Environment, Rome, 251 - 281. 
[7] FCA Meteorological Centre. (2016). Meteorological center data report. Federal College of Agriculture (FCA), Ishiagu, Nigeria.

[8] Awodoyin RO, Ogunyemi S and Ladipo DO. (2001). Studies on some nursery management techniques for Irvingia wombolu [syn. excelsa] ex. Okafor. Nigerian Journal of Ecology, 3, 24-28.

[9] Hartmann HT, Kester DE, Davies Jr FT and Geneve RL. (2007). Plant Propagation: principles and practices (7 ${ }^{\text {th }}$ edition). Prentice- Hall Inc., New Delhi, 293- 603.

[10] Rao NK, Hanson J, Dullo ME, Ghosh K, Nowell D and Larinde M. (2006). Manual of seed handling in genebanks. Handbooks for genebanks. Biodiversity International, Rome, 50-76.

[11] Hong TD and Ellis RH. (1996). A protocol to determine seed storage behavior. IPGRI Technical Bulletin No. 1. International Plant Genetic Resources Institute (IPGRI), Rome, 25 - 37.

[12] Acquoah G. (2004). Horticulture: principles and practices. 2nd ed. Prentice - Hall Press, New Delhi, 316-356.

[13] Chadha KL. (2009). Handbook of horticulture. Indian Council of Agricultural Research, New Delhi, 76-82.

[14] Baskin CC and Baskin JM. (1998). Seeds: Ecology, biogeography and evolution of dormancy and germination. New York Academic Press, New York, 666.

[15] Ehiagbonare JE and Onyibe HI. (2008). Studies on raising and preparation of planting stock of three indigenous forest timber species in Nigeria. International Journal of Biological and Chemical Sciences, 2(4), 573-578.

[16] Tsobeng A, Asaah E, Makueti J, Tchoundjeu Z and Damme PV. (2013). Propagation of Pentaclethra macrophylla Benth. (Fabaceae) through seed and rooting of leafy stem cuttings. International Journal of Agronomy and Agricultural Research, 3 (12), 10-20.

[17] Omokhua GE, Aigbe HI and Uko IJ. (2015). Effect of pre-treatments on germination and early seedling growth of Maesobotrya barteri. International Journal of Scientific and Engineering Research, 6 (3), 921-925.

[18] Agba OA, Asiebgu JU and Omaliko CPE. (2001). Effect of length of soaking in water at room temperature and soaking in hot water treatments on the germination of Mucuna flagellipes (Vogel. ex Hook) seeds. In Proceedings of annual conference of Horticultural Society of Nigeria. University of Nigeria, Nsukka, 130 - 132.

[19] Aliero BL. (2004). Effects of sulphuric acid, mechanical scarification and wet heat treatments on germination of seeds of African locust bean tree (Parkia biglobosa). African Journal of Biotechnology, 3 (3), 179 - 181.

\section{How to cite this article}

Ogbu JU and Otah OI (2017). Germination response of velvet tamarind (Dialium guineense Willd.) seeds treated with pre-sowing soaking in water at varying temperatures and durations. GSC Biological and Pharmaceutical Sciences, 1(2), 07-12. 